\title{
Schleiermacher on Language, Religious Feeling, and the Ineffable
}

\author{
ERIC SEAN NELSON \\ University of Toledo
}

\begin{abstract}
Aвstract: This paper is about the relevance of the ineffable and the singular to hermeneutics. I respond to standard criticisms of Friedrich Schleiermacher by Karl Barth and Hans-Georg Gadamer in order to clarify his understanding of language, interpretation, and religion. Schleiermacher's "indicative hermeneutics" is developed in the context of the ethical significance of communication and the ineffable. The notion of trace is employed in order to interpret the paradox of speaking about that which cannot be spoken. The trace is not a brute singularity but bears a fundamental relationship to the word — and ultimately the word of God—for Schleiermacher.
\end{abstract}

"Wer sich zu einem bestimmten Wesen bilden will, dem muss der Sinn geöffnet sein für Alles was er nicht ist.” —Friedrich Schleiermacher, Monologen (M). ${ }^{1}$

\section{LANGUAGE AND THE INEFFABLE}

\begin{abstract}
A ccording to Schleiermacher, in lecture 17 of the Dialectic of 1811 (DAP), "The deity is just as surely incomprehensible as the knowledge of it is the basis of all knowledge. Exactly the same is true also on the side of feeling." It can well be asked how a relation to the incomprehensible is the basis of comprehension and further how a relation to the ineffable is the opening of the possibility of communication (Mitteilung) and language (Sprache). Yet in On Religion: Speeches to its Cultured Despisers (UR), ${ }^{3}$ and in other early writings, this is what Schleiermacher suggested. This possibility of relating to the nonrelational in feeling and intuition, of articulating the traces ${ }^{4}$ of the infinite that interrupt the closure of finitude and immanence, suggests the limits and possibilities of hermeneutics understood as interpretation through discourse and language. ${ }^{5}$
\end{abstract}


Schleiermacher defined hermeneutics as the art of understanding. As such, hermeneutics is an art, concerned with language, through which we interpret more than texts and indirectly understand others. This art has three levels: (1) the everyday use of language, (2), the skilled use of language, and (3) the reflective use of language. Although hermeneutics is concerned with understanding, it is so only through language. Consequently, according to Schleiermacher: "Language is the only presupposition in hermeneutics, and everything that is to be found, including the other objective and subjective presuppositions, must be discovered in language." In his earlier work On Religion, Schleiermacher is also concerned with language. The language of religion is fundamentally communication or Mitteilung (UR, 11) just as in The Christian Faith (CG) the philosophy of religion is the phenomenological investigation of the forms of religious community and consciousness. ${ }^{7}$ Yet religion demands a certain kind of communication as it does a particular form of community. Religion involves a communication about that which resists and withdraws from cognitive and theoretical knowledge, that which cannot be expressed in communication and yet demands a response in speech (UR, 11). Because the human disposition is fundamentally addressed (UR, 15) and attuned in feeling, it is called on to respond.

As Dilthey remarked in his work Schleiermacher's Hermeneutical System in Relation to Earlier Protestant Hermeneutics of 1860 (HSH), ${ }^{8}$ not only is hermeneutics essentially concerned with language but language itself has a hermeneutical character from the beginning ( $\mathrm{HSH}, 745)$ and, therefore, hermeneutics shares the structure-both the limits and possibilities — of language. If language is always already related to what cannot be said, then the incommunicable occurs as a limit and condition for hermeneutical understanding which cannot be sublimated and thus positively defines the tasks of interpretation. The object of understanding demands to be understood from out of itself (UR, 28) and accordingly that the one addressed be receptive to the claim being made. ${ }^{9}$ The further claim that hermeneutics is the art of understanding better than the author understands himself indicates the need in interpretation to consider the unthought of an author (HSH, 707).

Human life occurs through communication which is always interpretation. Even what is most basic to Schleiermacher's theological thought—God, Christ, and the Holy Spirit — calls for interpretation. The Holy Spirit or divine inspiration also involves an interpretive activity (HHM,67) even in its fundamental receptivity or responsiveness. Both the revealed word and the preached word inherently call for human activities of interpretation in regard to that which is beyond and potentially transforms human language and understanding. Karl Barth objected that this thesis undermines the ancient doctrine of divine inspiration - why should God not be able to make the divine word transparent (Barth, 183)? According to the logic of Schleiermacher's argument, however, Barth's counterclaim presup- 
poses that it is actually an option to replace interpretation with inspiration (i.e., the human with the divine), and that Christians can do without the interpretive event which addresses and calls forth a human response-and thus interpretation - to the divine in feeling and language.

For Schleiermacher, the religious word speaks first of all to feeling and disposition. What moves us in feeling demands to be articulated and clarified (CG, 23). Moreover, insofar as thinking intends to be a knowing, it strives to be communicated (DAP, 56).Communication is the only means through which humans, as beings who think, feel, and act, can partially come to self-knowledge. However, human knowledge is more than simply incomplete. Knowing occurs in relation to an infinity of differences, according to his Dialectic of $1814 / 15$ (D, 24-25), ${ }^{10}$ and to the incomprehensible in the lectures on dialectic of 1811 (DAP, 31). Therefore, the ineffable can be said to function in this discourse in two ways: (1) the infinite that can never be finitely determined whether as a universal concept or a particular thing and (2) the singular that both discloses and conceals itself in discourse such that it can never be fully brought to language.

\section{The Limits of Hermeneutics and its Philosophical Context}

Schleiermacher has been criticized by Gadamer and others ${ }^{11}$ for limiting hermeneutics to a doctrine of art (Kunstlehre) oriented according to the idea of understanding correctly given the universality of misunderstanding. ${ }^{12}$ According to Gadamer, Schleiermacher missed the philosophical dimension of hermeneutics in which understanding is to be interpreted ontologically as the way humans are in the world and in a tradition. Schleiermacher consequently oriented hermeneutics as a doctrine of art to a false scientific idea of method and took understanding to aim at correctness rather than the disclosure of the happening of truth. The idea of correctness introduced a false emphasis on psychological interpretation in which the interpreter attempts to identify with the author's psychology rather than with the truth of what the author claims.

However, Gadamer's critique is in danger of conflating the difference between art and science. As with Kant, the practice of art is not the doctrine of science nor does art deductively or mechanically apply rules and method. ${ }^{13}$ Art can never be solely based on rules, since this would involve the infinite regress of always needing another rule to apply a rule. Art then requires judgment or a sense of appropriate application that is cultivated. Kant makes this distinction clear in the Critique of Judgment: Whereas science demands determinate judgment, which subsumes a particular under a concept, art calls for reflective judgment, which articulates the general from the particular - that is, without a pregiven rule. ${ }^{14}$

For Schleiermacher, art is not the imposition of science onto tradition or system onto the life-world. Art originates in ordinary experience itself. It is always already 
at work in ordinary understanding (HHM, 49) to the degree that even the child is engaged in the art of hermeneutics in language acquisition (HHM, 52). Art is practiced by a finite sensuous being because there is no rule for how to apply a rule. Method alone is insufficient for both Schleiermacher and Dilthey, since it is the cultivation of a sense already at work in everyday communication and as such it requires lived experience (HSH, 605) ${ }^{15}$ Although the goal of scientific correctness is an important one in Schleiermacher's hermeneutics, as Dilthey noted, art and imagination characterize all knowing ( $\mathrm{HSH}, 695)$. Cognitive representation is necessary for the work of the sciences. Yet it is not itself primary since it is always based on prior feeling. Schleiermacher is consequently already engaged in a critique of a purely representational model of knowledge. Schleiermacher insisted on the priority of feeling in understanding the human agent and, as we shall see, the receptivity and responsiveness of the imagination in interpreting others through their expressions. In this sense, one of the strengths of "romantic hermeneutics" is that it recognizes the role of feeling, desire, and eros in interpretation. ${ }^{16}$

The emphasis on psychological understanding is subsequently not so much representational reproduction demanding correctness as it is a receptivity to the traces of the singularity of the other as they are indicated in communication. ${ }^{17}$ As Dilthey argued in his reading of Schleiermacher, the individual and the singular would be lost in a discourse that denies the possibility of psychological interpretation (HSH, 717-718). The potential loss of this dimension in Gadamer and contemporary hermeneutics does not necessarily constitute a progress from epistemology to ontology. This advance forgets the question of the singular that ought to be central to hermeneutical understanding.

Although hermeneutics is universal as a universal doctrine of art applicable to all forms of communication, Schleiermacher failed to achieve the universality of hermeneutics (as understanding) demanded by Gadamer in the wake of Heidegger's groundbreaking analysis of understanding as our way of being in the world. Gadamer's criticisms are only partially answerable based on the resources of Schleiermacher's hermeneutical writings, since the word hermeneutics did not achieve a universal employment in Schleiermacher's thought. It remained of limited scope in that philosophy and human existence are not to be identified with what is gained through hermeneutics.

There is a crucial difference in aims between the hermeneutics of Gadamer and Schleiermacher. For Gadamer, hermeneutics should integrate rather than reconstruct and thus follow Hegel's rather than Schleiermacher's example (TM, 165-169). There are at least two problems with this contrast: (1) Schleiermacher's approach is not an "external reconstruction" but is receptivity to what addresses and claims us; and (2) Schleiermacher also noted the integrating and mediating character of language. Although he emphasized the unifying and conforming power of language and tradition, Schleiermacher also showed the importance of 
linguistic transformation such as in the artist of language who each time individualizes language anew (HHM, 49) and in the language forming power of the new and the individual. ${ }^{18}$ Although it is surely appropriate to be wary of the exaggerated claims of genius found in romantic aesthetics, which Gadamer analyzed so well, this suspicion or disenchantment of the different, individual, and singular ignores their potential disruptive or transformative power. ${ }^{19}$ Schleiermacher's approach to language emphasized the differences that occur in relation to the identity of language; that is, with that which differentiates languages and, further, resists and withdraws from linguistic mediation. Hermeneutics concerns language, which is the only presupposition and defines the scope of hermeneutics (HHM, 50), but language cannot close itself to what is other than language in a pure immanence of linguistic integration or mediation. Despite the limits that language and thus hermeneutics might impose, these limits cannot eliminate the infinity of sense (HHM, 53), the infinite significance of a book such as the Bible (HHM, 55), or the relation of the finite to the infinite. The incommunicable confronts language both on the side of the whole and the individual.

Jean Grondin has emphasized the quest for the whole understood as completeness in romantic hermeneutics. ${ }^{20}$ Yet the whole is not so much a complete system as it is an infinity of intercrossing relations that are ultimately referred to the non-relational. Along these lines, Dilthey characterized three senses of "whole" in Schleiermacher's thought: (1) organizing inner form, (2) system, and (3) relational context or Zusammenhang (HSH, 679). Whereas organic inner form refers to an immanent teleology and the idea of a system points to the completeness of a totality, Zusammenhang indicates the contextuality which is interpreted as singularity in relation to infinity. If there is a common quest in romantic hermeneutics, it is characterized more by the question of the singular and the ineffable than it is by the systematic completeness of representational knowledge. Dilthey could therefore suggest that individuality is the form of the whole (HSH, 709) and if we could know the whole, then we would know the whole in its concrete singularity rather than as a universal or concept.

Gadamer's criticisms are thus answerable if we turn to Schleiermacher's larger philosophical project in its hermeneutical significance. The debate between traditional and universal hermeneutics is not so much about the correctness of Gadamer's criticisms but, more significantly, about the nature and tasks of hermeneutics itself. Schleiermacher did not name his larger philosophical project hermeneutics and yet it is hermeneutical in the sense that it does reflect a fundamental concern with the scope and limits of understanding and communication between individuals and communities. This might be thought to be more properly hermeneutics, given the tradition as a whole beyond its twentieth-century appropriation, since it is directed both at questions of self and other as well as language and the ineffable. ${ }^{21}$ 
If Schleiermacher's hermeneutics emphasized the correctness of an understanding to be guided by the theoretical articulation of an art and practice, this is far from meaning that he presupposed correctness as the sole model of truth, since interpretation calls for responsive feeling and imagination. Nor does this imply that the world is inherently and fully comprehensible and intelligible, since as finite beings we relate to the infinite through what Schleiermacher called in various places traces and seeds (Spuren und Keime). The notion of trace-developed in the works of Levinas and Derrida-is helpful for interpreting its use in Schleiermacher and the paradox of speaking about that which cannot be spoken. The trace is that which is given as not being able to be given, the presence of that which cannot be thought as presence, the disclosure of non-disclosedness, the revelation of that which is concealed as concealed. However, the trace does not stand alone as a brute singularity or fact, since it bears a fundamental relationship to the word - and ultimately the word of God — for Schleiermacher.

Further, Schleiermacher's denial of truth as correctness and as system characterized his confrontation with the Idealism of Fichte, Schelling, and Hegel. Instead of the purity of knowledge, Schleiermacher asserted in his Dialectic of 1814/15 an infinite difference (D, 24-25), criticizing such idealism for the sake of the individual $(D, 35)$. The individual is not characterized by freedom or spontaneity alone, as it was for many of his contemporaries, but also by relative and absolute dependence. ${ }^{22}$ This dependence suggests a fundamental receptivity that determines how humans are in the world and their being toward that which is outside the human world (CG, 19-20). Insofar as this dependence is not a mere passive dependency, it involves some sort of activity. Dependence requires namely the activity of a receptivity - which Schleiermacher sometimes described as a minimal point of activity - that is claimed by and responds to that which is indicated in the feeling of dependence. Since this receptivity is not simply an effect of a cause or a pure dependency, it would be appropriate to use the word "responsiveness" to describe it. ${ }^{23}$ The responsiveness of the feeling of absolute dependence in faith, which is neither purely active nor passive, parallels the responsive feeling of life in Kant's Critique of Judgment. ${ }^{24}$

As a fundamental feeling, dependence is non-representational. It cannot simply be thought in concepts. It reveals itself instead in feeling, which is prior to and the basis of knowledge (OG, 40), ${ }^{25}$ and is understood as being-moved by something that is other than oneself $(C G, 10)$. Human motility is rooted in the capacity to be moved, human receptiveness in feeling and thought is made possible in being addressed, such that human life is a response to and participates in the divine.

Schleiermacher's hermeneutics is thus in a sense "limited" or, more precisely, "indicative." For Schleiermacher, language is not exhausted in reference but opens up in expression, indication, performance, and suggestion. In the Speeches and the Monologen, Schleiermacher developed a language of indication (Andeutung) 
which emphasized the indirect approach to that which cannot be directly referred to or said. This "hermeneutics" of indication, which was at work before he made his hermeneutics explicit, allows us to rethink the hermeneutical import of his thought. Schleiermacher's mature hermeneutics, which retained the importance of the individual and the community by distinguishing psychological and linguistic interpretation, needs to be articulated in relation to its context from which we can draw out the hermeneutical import of his philosophy.

Language is fundamentally communication. As communication, language is both already ethical and already tied to that which can never be fully brought to language - the infinite. Schleiermacher suggested in his On Religion that communication arises as a need from our experience of the traces of the infinite and the ineffable in our non-representational experience-namely, in feeling. In the early chapters of his later theological treatise The Christian Faith, Schleiermacher articulated how the feeling of piety cannot be explained as an intentional relation to an object (CG, 8-9). Rather than being a mere transmission of information, communication is in both works that which binds addresser and addressee. Still, how can one speak of address in the case of the ineffable and infinite? How are we spoken to in and through the faith - the faith that Schleiermacher defined early in his life as the feeling or sense and taste of the infinite (UR, 36) and later as the feeling of absolute dependence (CG, 16)?

\section{The Hermeneutical Import of Schleiermacher’s Philosophy}

In light of the questions considered above, the hermeneutical import of Schleiermacher's philosophy can be unfolded in at least three ways. These will be explored in the next three sections.

$i$.

Schleiermacher's lectures and writings on ethics, politics and society indicate the fundamental importance of sociability and communication. ${ }^{26}$ As Dilthey, Gunter Scholtz, and James Brandt have argued, ethics is the basic motive and concern of Schleiermacher's intellectual endeavors. ${ }^{27}$ In particular, his account of the sociality of human life should be the orienting point for considering the hermeneutical significance of his works. Communication is not oriented toward correctness-as the identity of saying and what is said or between the mental states of speakers-or the integrating ideas of mediation or consensus as Gadamer or Habermas have articulated it.Communication is not exhausted in communication about the general and universal, communication is the enactment, exhibition, and performance of individuality in language. I am claimed by the speech of others and respond by communicating who I am (compare UR, 5). It follows that communication is not only a discussion of objects or of what from a third-person perspective. 
Communication concerns the first person singular and plural. That is, the question of who speaks and is spoken to. In asking who rather than what, one can appropriately answer through a name or personal pronouns such as "I" or "you." In addressing and in being addressed as "who," communication is already inherently interpersonal and ethical. The psychological dimension of hermeneutics, since it suggests interpretive rather than explanatory psychology, refers to the question who. The question of the who demands an articulation of singularity, a singularity that defies full disclosure. For Dilthey, this difference in language-i.e., the difference between the first and third person perspectives - is what distinguishes lived-experience (Erlebnis) from experience (Erfahrung). ${ }^{28}$

The decentering of the modern idea of the subject was already at work in a modernist such as Schleiermacher when he emphasized the fundamental receptivity and dependence of the self. The decentering of the subject, as understood through certainty and autonomy, does not eliminate but radically opens up the question of the who as someone other than constituting or constituted. Thus, Schleiermacher can discuss the co-constitution or, in Heidegger's language, equiprimordiality of self and world, self and other, in the opening chapters of The Christian Faith. This epistemological point is closely related to the ethical point that we can only become who we are through others (CG, 18). In both his early and late work, language has claimed us. We are claimed not only by an absolute dependence on God, but by a plurality of others on whom we are relatively dependent.

In his addresses On Religion, communication provides the opportunity for recognizing the positive character of actual beliefs and practices in their variation and plurality. Religious faith presents individuality in relation to infinity or individuality as absolute dependence. Religious faith is not simply a matter of reproducing the thought and feeling of another, nor does it mean that an agreement has to be achieved that would eliminate the differences between individuals and their respective perspectives. These differences are given a positive and necessary character, such that they are neither accidental to religion nor to be overcome in the unity of one religious belief or institution. This recognition of the fundamental plurality of religious life is what calls forth communication and is a goal of a communication oriented toward being receptive to others from out of their own perspectives. The recognition of religious difference is thus itself essential to religious understanding.

ii.

The ethical demand implicit in communication can be articulated from Schleiermacher's concern for individuality and infinity, especially in On Religion and in the Monologues. Individuality and infinity as positive phenomena are not only the limits of communication and hermeneutics but are their goal and motivation. Communication is therefore not the overcoming of individuality in 
common life but it is its presentation in forms of speech that cannot be reduced to the universality of propositions and concepts.

An enactment of my individuality in relation to what I am and my context can occur, for example, in testimony and witnessing. Testimony can present the life of religious feeling and community. It is the articulation of the singularity of myself, others and God. This singularity is communicated, although it is not a particular that can be subsumed under or deduced from a universal. Such a form of communication addresses and responds rather than explains or convinces. Only such forms of communication can begin to be adequate to that which resists and escapes ourselves, our theories, concepts and propositions. Through speech such as testimony we indirectly indicate that which cannot be made explicit or mastered. We suggest through such communication that which cannot be communicated. These traces are suggested in experiences of individuality, the infinity of a whole that withdraws from attempts to achieve systematic totality.

According to Schleiermacher, there is a divine excess that destroys uniformity and homogeneity, whereas the desire for system rejects what is foreign including the excess of the divine (UR, 44). Schleiermacher thus suggested that if there were only a finite world of conflict and destruction, then the singular would be lost. Schleiermacher argued, perhaps paradoxically from the perspective of contemporary French philosophy, for the singular by way of an infinite whole that would preserve the singular precisely in its singularity. Schleiermacher could thus claim that "everything is one and everything is true" and that this is precisely the condition of singularity, of unlimited difference, and plurality (UR, 44). Relational context (Zusammenhang), as developed in Schleiermacher and Dilthey, would allow for a holism that requires the singular and an individualism that requires the whole.

iii.

Schleiermacher remained committed to the articulation of the importance of individuality and infinity in his later theological writings such as in The Christian Faith. Schleiermacher is concerned in this work and in On Religion, especially with the concluding address, with the truth of a positive religion called Christianity. Like Kant in Religion within the Limits of Mere Reason, Schleiermacher located the uniqueness of Christianity in its being a religion of redemption or salvation. For Kant, Christianity is a symbol of hope and the possibility of a revolution in moral attitude or character. ${ }^{29}$ Its justification is ethical. For Schleiermacher, religion can only receive its own immanent justification. He placed the particularity of Christian faith in the feeling of redemption that qualifies the feeling of absolute dependence $(O G, 70)$.

Although for Schleiermacher - as an elder, pastor, and theologian of the Reformed church who supported ecumenical reunion with the Lutheran church- 
Protestant Christianity best fulfills the feeling of absolute dependence in the doctrine of salvation by grace alone ${ }^{30}$ his privileging of Reformed Christianity is in tension - if not conflict - with his assertion of religious pluralism. Most problematic is his use of developmental stages (in order: animism, polytheism, monotheism; Islam, Judaism, Christianity, and Protestant Christianity). Interestingly, Dilthey (Schleiermacher's hermeneutical successor) criticized the use of such explanatory schemas in the human sciences and argued that Schleiermacher misunderstood and undermined historicity in using such a developmental schema. ${ }^{31}$ One should also keep in mind the uses that such developmental schemas and orientalism were put to in justifying European colonialism. Orientalism constitutes the East as surpassed and decayed origin that is in need of Western deliverance. ${ }^{32}$

Nevertheless, all religions embody and express truth. Schleiermacher argued that every religion in one way or another is an interpretation and embodiment of this feeling of dependence. Schleiermacher rejected the enlightenment idea of a natural or universal religion, including its Kantian moral form, because it suppresses the particularity of religious feeling and communication. To be religious is to belong to a particular positive religion (OG, 42). The articulation of a particular positive religion requires the recognition of a singular that cannot prove but can claim universality only insofar as it is one way of presenting and enacting the infinite. ${ }^{33}$

Gianni Vattimo, in his essay on the return to religion in contemporary thought, entitled "The Trace of the Trace," points out that this return is inherently connected with the concept of positivity in a double sense: (1) as historicity and (2) as facticity. ${ }^{34}$ Positive religion would then be, according to the first sense, a historical determination of that which is outside history. Since we cannot directly or purely access the holy, we can only do so through the positivity of a particular religion in a particular time and place for Schleiermacher. Still the positivity of a particular religion is bound to the facticity of religious experience itself. Absolute dependence suggests the facticity of a finite being in relation to the infinite and the holy. Vattimo can thus claim "that the bare fact of returning denotes positivity as a constitutive feature of religion, in as much as religion depends on an originary facticity [italics mine, translation altered] that happens to be legible as createdness and dependence (in Schleiermacher's sense perhaps)" (Vattimo, 1998, 85). This is a crucial point because religion does not simply demand commitment because it is a custom or convention of a particular society (i.e., because it is positive). Instead positive religion with all of its customs, conventions, and institutions is how that which is outside all positivity and historicity is determined and interpreted. Positive religion is the explication, both necessary and without end, of factical religion. This positivity is infinitely referred to the facticity of religious experience itself, which following Schleiermacher is a feeling of the infinite and, more precisely, the feeling of absolute dependence. 
Karl Barth confuses facticity with factuality, historicity with history, in his critique of Schleiermacher, since he does not recognize in the factical and the historical anything but factual data that is nothing more than "reality and only reality" (Barth, 172) and "the burden of [theology's] own historicity and relativity, of the inadequacy of all human words" which theology needs to overcome (Barth, 176). Yet, for Schleiermacher, the sense of religion and the religious sense are not exhausted in positive religions or their scientific study. Religion is not only an object of study but an activity of passivity, since it is the feeling of absolute dependence. The fundamental mood or attunement (Stimmung) of religion is accordingly responsiveness in the acknowledgment of this absolute dependence. In the feeling of absolute dependence, Schleiermacher points out how the receptivity fundamental to our being is spoken to or addressed ("anspricht") in faith $(\mathrm{CG}, 19)$. As addressed, we are attuned (bestimmt) or called to respond from out of our receptivity. This fundamental receptivity is a being moved by something other than oneself. A positive religion differs from the positivity or factuality of other existing phenomena such as the state insofar as it calls forth a receptivity to that which is other than oneself, to God as the word that indicates that which cannot be named, to God as the infinite and the holy. ${ }^{35}$ It is, in the language of Levinas, an absolute otherness or alterity since participation does not imply that I can assume comprehension of or identity with God. God can be thought of as either absolute alterity or absolute identity, but we are not in the position to think with Hegel the identity of identity and difference.

This argument is not uncontroversial. Karl Barth disparaged Schleiermacher's claim that the word of God is related to the unnamable- or that saying is conditioned by the unsayable - for two reasons: (1) if something is truly ineffable, the best response is to be silent, and (2) faith in the word of the Lord eliminates any reason to speak of the unknowable (Barth, 176). Barth thus rejected both interpretation and the ineffable because of the word, whereas Schleiermacher justified them through the word. Their disagreement rests on the nature of language-i.e., on whether the word is fixed via the intention of the absolute author or whether language is an event in which the human and non-human, the sayable and the unsayable intersect.

Religion is thus underway to the feeling of absolute dependence on something other than oneself, yet it still indicates and singles out the self that is in question in this very relation. According to Schleiermacher, absolute dependence on something other than one's own self (in all its self-interest) is possible only in there being a self. Further, absolute dependence can only be dependence on one being and thus implies monotheism. This appeal includes the demand for the recognition of my dependence on other beings as well as that which is inadequately understood when we call it a being. Religion, as an originary facticity, is the condition of openness, of receptivity and responsivity. These do not remain simply 
mute but call forth our joys and sorrows to come to expression and action. They demand a communication of self and other because one cannot do otherwise than enact the response that one is to the infinite and holy as it takes form in the singularity of absolute dependence and the particularity of a positive religion.

One might ask at this point: does the finitude of our knowledge in relation to infinity delivers us into the evil of irrationality? According to Schleiermacher, acknowledging limits to knowledge does not mean to abandon knowledge. The recognition of limits to knowledge indicates instead the task for faith. This faith does not embrace the negative and irrational, it attempts to know and clarify itself. This faith does not allow questioning to stop in the face of a mystery. Rather, it is the pursuit of knowledge in the recognition that this self-reflective faith cannot be established as a science. The finitude of knowledge does not therefore deliver us into the irrational but compels us to a reflection that need not be a universal knowing. Instead we are open to the particular and the singular and these call us forth to communication.

This point can be made in another way by paraphrasing the conclusion of Karl Jaspers' Der philosophische Glaube, a work that parallels Schleiermacher's insistence on the need for communication in relation to an infinite whole (the encompassing): We understand today, in our lack and need (Not), that communication fundamentally claims and addresses us. The clarification of communication out of its plural origins in the modes of the encompassing (Umgreifende) is a central theme of philosophy and it is a daily task of philosophical life to bring closer all the possibilities of the realization of communication. ${ }^{36}$

\section{Conclusion: Implications For a Responsive HeRmeneutics}

In the proceeding thoughts we find an alternative way of thinking about what is essential to hermeneutics. In reading Schleiermacher's works we can articulate indications of the positive character of difference, of the individual in its singularity, of infinity and that which addresses us without our being able to determine it. Despite the limits of Schleiermacher's philosophy and hermeneutics, we can work from this basis in order to consider the implications of individuality, infinity, and responsivity (which present us with the limits of knowing and understanding) for the articulation of the aims of knowledge and understanding in the arts of dialectic and hermeneutics.

Instead of seeking to eliminate the singular in its infinity, that which escapes understanding, because it does not understand it, understanding can enact and speak of its relation to the unthought and the unthinkable. The experience of the ineffable suggests the task of a responsiveness without end, a task that does not eliminate the question of difference in demanding the exclusive and determinate universality of a supposed correctness or consensus, but allows us to respond to 
the occurrence of the infinite, the individual, and the holy. This appeal cannot be made without the demand for universality that is essential to the articulation of the singular. The singular is not a mere singularity, but a relation between the universal and the unique or the distinctive. Because of this demand of recognition, this appeal constitutes an occurrence that cannot help but require the ethical response and responsibility of unfolding our own and others' individuality and community.

In communication with others we are already in relation to the infinite, which breaks through the finite immanence of the meanings and projects of the "I" or "we." The infinity and dependence indicated in faith is tied to our openness to our dependence on others and their singularity. In communication we are therefore spoken to and claimed by the other to whom we must respond. In feeling, we can be spoken to in and through faith, by that which calls me to further reflection out of exposure to the unique and in the trace of the ineffable. ${ }^{37}$

\section{NoTeS}

1. Friedrich Schleiermacher, Monologen (Hamburg: Meiner, 1978, 3rd edition), 37.

2. Friedrich Schleiermacher, Dialectic or the Art of Doing Philosophy (1811), trans. Terrence Tice (Atlanta: Scholars Press, 1996), 31.

3. Friedrich Schleiermacher, Über die Religion (Stuttgart: Reclam, 1969); On Religion: Speeches to Its Cultured Despisers, trans. Richard Crouter (Cambridge: Cambridge University Press, 1988).

4. James Mensch has argued that the notion of trace developed in the writings of Derrida and Levinas is already at work in Kant's understanding of the supersensible. See his "Temporalization as the Trace of the Subject." Kant und die Berliner Aufklärung, ed. V. Gerhardt, R. Horstmann, and R. Schumacher (Berlin: Walter de Gruyter, 2001). As I hope to show, the notion of Spur as trace is not foreign to Schleiermacher's articulation of the human relation to the infinite and the holy. For Schleiermacher, traces are revealed in the receptiveness and dependence of feeling.

5. Manfred Frank has explored the relation between Schleiermacher and contemporary French philosophy in his Das individuelle Allgemeine (Frankfurt: Suhrkamp, 1977). Unfortunately, he has not discussed Schleiermacher and Levinas, who both emphasized the ethical importance of dependence, passivity, and receptivity. The use of the concept of responsivity in my discussion might seem anachronistic yet, as I hope to show in this paper, it is not inappropriate. Bernhard Waldenfels has elaborated a critique of Gadamer that brings the notion of responsiveness and singularity closer to Schleiermacher in his Vielstimmigkeit der Rede (Frankfurt: Suhrkamp, 1999).

6. HHM: Friedrich Schleiermacher, Hermeneutics: The Handwritten Manuscripts, trans. James Duke and Jack Forstman (Atlanta: Scholars Press, 1997, 2nd edition), 50.

7. Friedrich Schleiermacher, Der christliche Glaube (Berlin: Walter de Gruyter, 1999), 7. Karl Barth's critique of a reduction of God to the individual's subjective consciousness and experience of God misses the point, since Schleiermacher (1) describes this 
consciousness and experience as pointing beyond itself in its dependence on and responsiveness to God and (2) explores the fundamentally communal and communicative character of religious faith. See Karl Barth, The Theology of Schleiermacher (Grand Rapids: Eerdmans, 1982), especially 187-188.

8. Wilhelm Dilthey, Hermeneutics and the Study of History, ed. Rudolf Makkreel and Frithjof Rodi (Princeton, N.J.: Princeton University Press, 1996), 33-227.

9. This connection between responsiveness and immanence is further developed by Dilthey - for example, in the thesis that life needs to be articulated from out of itself - and by Heidegger (circa 1920) in describing the hermeneutics of facticity as the self-articulation of life in its enactment. See my "Begründbarkeit und Unergründlichkeit bei Wilhelm Dilthey." Existentia 12:1-2 (2002), 1-10.

10. D: Friedrich Schleiermacher, Dialektik (1814/15) \& Einleitung zur Dialektik (1833) (Hamburg: Meiner, 1988).

11. Most notably Habermas. Despite the many differences between Gadamer and Habermas, they both consider hermeneutics a question of consensus - either through sensus communis and tradition or through rational argument and deliberative democracy.

12. Hans-Georg Gadamer developed his critique of Schleiermacher, which is preliminary and secondary to his evaluation of Dilthey's hermeneutics, in “The Questionableness of Hermeneutics" section of Truth and Method (New York: Continuum, 1989, 2nd edition), 173-197. Hereafter cited as TM. Note that I will only use the criticisms offered by Barth and Gadamer as argumentative foils rather than providing a detailed account of their positions.

13. See TM, xxiii. Compare my discussion of the distinction between art and science in Kant in "Kant and the Art of Political Prudence." Kant und die Berliner Aufklärung, ed.V.Gerhardt, R. Horstmann, and R.Schumacher, volume 4 (Berlin: Walter de Gruyter, 2001), 220-227.

14. For a detailed examination of this distinction and its implications, see Rudolf Makkreel, Imagination and Interpretation in Kant (Chicago: University of Chicago Press, 1990).

15. Also compare Dilthey's criticism of rule-based hermeneutics (HSH, 710).

16. Julie Ellson has analyzed the "hermeneutics of desire" and its gendered character in Schleiermacher, who often ethically and aesthetically privileges the feminine, and romanticism in Delicate Subjects: Romanticism, Gender, and the Ethics of Understanding (Ithaca, N.Y.: Cornell University Press, 1990). In his 1919/1920 lecture-course, Grundprobleme der Phänomenologie (Frankfurt: Klostermann, 1992), Heidegger preserves this aspect of hermeneutics when he spoke of Hingabe (giving oneself over to) and the eros in which one lets oneself go (sich-los-lassen) into life (Gesamtausgabe 58, 168 and 263).

17. I will distinguish "singular" and "particular" throughout this essay. The singular is the unique as exception and indicates "facticity," the particular is the uniqueness of a person or people that can still be comprehended in relation to laws and universals. It indicates "positivity." Individuality can be understood in terms of both the exception and the rule. 
18. HC: Friedrich Schleiermacher, Hermeneutics and Criticism, ed. Andrew Bowie (Cambridge: Cambridge University Press, 1998), 12, 86.

19. Gadamer criticized the spontaneity and individuality of "genius" in Kant (TM, 55-60) and Schleiermacher (TM, 188-189).

20. Jean Grondin, Introduction to Philosophical Hermeneutics (New Haven, Conn.: Yale University Press, 1994), 64.

21. In this sense, some authors who explicitly reject hermeneutics — such as Derrida and Levinas - are engaged in hermeneutical questions.

22. Compare this discussion of absolute dependence with the analysis of Ben Vedder in his "Schleiermacher's Idea of Hermeneutics and the Feeling of Absolute Dependence," Epoché 2:1 (1999), 91-111.

23. Although perhaps currently associated with recent French thought, this word has been used - since at least the 1960s — in the English language reception of European and Asian philosophy.

24. Compare Makkreel's investigation of the feeling of life (Lebensgefühl) in Kant in his Imagination and Interpretation in Kant (1990), 94 and 106. Schleiermacher, especially in his early works, emphasized "the feeling of life." Karl Barth gives this a biologistic meaning (Barth, 148), although Christianity itself has used life as a metaphor which indicates more than biological life. There have been a number of excellent studies on life in Schleiermacher, including its sources in Spinoza and Kant: Albert Blackwell, Schleiermacher's Early Philosophy of Life (Chico, Calif.: Scholars Press, 1982); Julia Lamm, The Living God: Schleiermacher's Theological Appropriation of Spinoza (University Park: Penn State University Press, 1996).

25. OG: Friedrich Schleiermacher, On the Glaubenslehre, trans. James Duke and Francis Fiorenza (Atlanta: Scholars Press, 1981).

26. James Brandt explores the social-political implications of Schleiermacher's religious ethics, including his attempts at reforming church and society, in All Things New: Reform of Church and Society in Schleiermacher's Christian Ethics (Louisville: Westminster John Knox, 2001).

27. See HSH, 671, as well as Gunter Scholz, Ethik und Hermeneutik (Frankfurt: Suhrkamp, 1995), 16 and 86.

28. See Matthias Jung's exposition of this point in his Erfahrung und Religion (Freiburg: Alber, 1999), especially 9-14 and 274-275. Compare Gadamer's critique of Erlebnis in TM, 60-70. Gadamer objects to the closeness of Erlebnis to Ergebnis (result), but in Dilthey Ergebnis can refer to the givenness (Gegebenheit) related to facticity and historicity (TM, 64-65 and Nelson [2002], 3-4, 6).

29. Immanuel Kant, Religion within the Boundaries of Mere Reason and other Writings, ed.Allen Wood and George di Giovanni (Cambridge: Cambridge University Press, 1998), 6, 46-47, 124-137.

30. That is, for Schleiermacher, grace is the highest form of dependence as receptivity. Kant also speaks positively of the receptivity involved in grace but for him it means the possibility of moral transformation and thus does not contradict his claim that man has to make himself worthy of such help (Kant, 6: 44-45). 
31. For Dilthey, Christianity is one unique but finite expression of the feeling of life and its articulation into a worldview. It is an authentic yet one-sided revelation of human life like every other religion. See Matthias Jung, Dilthey zur Einführung (Hamburg: Junius, 1996), 19.

32. See Edward Said, Orientalism (New York: Vintage, 1978), 108-109. Although Said focuses on the connection between English and French colonialism and orientalism, he also discusses the use of developmental schemas in German thinkers such as Herder, Humboldt, and Marx.

33. Religion is constituted by the relation to the infinite and invisible, according to Dilthey in his Von Deutscher Dichtung und Musik (Teubner: Leipzig, 1933, 2nd edition [hereafter cited as DDM]),55. Dilthey argued that the peculiarity of a religion derives from how it relates to the infinite. Thus, for example, Christianity is how it relates to the infinite by emphasizing the infinite as such and by letting every aspect of itself be informed by the infinite: "Das christlich-religiöse Bewußtsein erhebt das Göttesgefühl zu einem mystischen Erleben des Unendlichen. Diese Unendlichkeit gibt allen Bestandteilen des christlichen Bewußtseins ... ihren Charakter” (DDM, 197).

34. See Gianni Vattimo, “The Trace of a Trace," in Religion, ed. J. Derrida and G. Vattimo (Stanford, Calif.: Stanford University Press, 1998), 85. The translator chose the English word "factuality," but given Vattimo's emphasis, it would be better to distinguish facticity (as that which presents itself to us through resistance, reversal, and withdrawal) and factuality (being true or a fact, whether empirical or transcendental).

35. For a Calvinist such as Schleiermacher, God is fundamentally understood in relation to the word such that saying this word in religious speech is the sacrament. On the centrality of the word, the word as indication and enactment rather than referential, and Christ as the interpretive event of the word that calls forth human interpretation in Schleiermacher, see the excellent study by Dawn DeVries, Jesus Christ in the Preaching of Calvin and Schleiermacher (Louisville: Westminster John Knox, 1996).

36. Karl Jaspers, Der philosophische Glaube (München: Piper Verlag, 1948), 136.

37. I would like to thank the organizers and participants of the Schleiermacher as Philosopher and Theologian conference at Drew University, where I presented an earlier version of this paper. I would also like to express my gratitude to Elizabeth Corrie, Rudolf Makkreel, and Terrence Tice for discussing an earlier draft of this paper with me. I am also thankful to the anonymous reviewer and Walter Brogan for their comments and suggestions. 